\title{
PEMILIHAN LOKASI BELANJA DAN PERILAKU PERJALANAN DI KOTA BANDUNG
}

\author{
Muhamad Rizki \\ Program Studi Teknik Sipil \\ Universitas Katolik Parahyangan \\ Jln. Ciumbuleuit 94, Bandung 40141 \\ Tlp. (022) 2033691 \\ Muhamadrizki1404@gmail.com
}

\author{
Tri Basuki Joewono \\ Program Studi Teknik Sipil \\ Universitas Katolik Parahyangan \\ Jln. Ciumbuleuit 94, Bandung 40141 \\ Tlp. (022) 2033691 \\ vftribas@unpar.ac.id
}

\begin{abstract}
Grocery shopping activities play substantial role in fulfilling individuals' daily-activities needs. Its spatialseparated location characteristics led to travel consequence. Grocery shopping activities and travels still partly contributed to several challenges on urban transportation, such as traffic congestion. This study aims to investigate the shopping location decision as a part of shoppers' spatial attribute. The analysis conducted based on data from a survey in Bandung City in 2017 which the shopping activities and travel characteristics were recorded. Result of analyses using classification analysis confirmed the hypotheses that there is positive interaction between travel characteristics, activity arrangements, and spatial conditions in selecting shopping location. It is found, similar region shopping location with resident area not necessarily lead to a choice. The study finds that the attractions offered by shopping locations influence location selection. In addition, the activity arrangement of shoppers through the trip chain were also found to influence the selection of shopping locations.
\end{abstract}

Keywords: grocery shopping, shopping location, travel characteristics, travel behavior

\begin{abstract}
Abstrak
Kegiatan belanja sehari-hari berperan penting dalam memenuhi kebutuhan aktivitas sehari-hari individu maupun rumah tangga. Karakteristik spasial lokasi belanja mengakibatkan konsekuensi pada perjalanan. Kegiatan dan perjalanan belanja sehari-hari berkontribusi pada permasalahan transportasi perkotaan. Penelitian ini bertujuan untuk menganalisis keputusan pemilihan lokasi belanja sebagai bagian dari atribut spasial pelaku belanja. Analisis dilakukan berdasarkan data survei wawancara di Kota Bandung tahun 2017 tentang kegiatan belanja dan karakteristik perjalanan. Hasil analisis menggunakan analisis klasifikasi mendukung hipotesis bahwa ada interaksi positif antara karakteristik perjalanan, pengaturan aktivitas, dan kondisi spasial dalam memilih jenis lokasi belanja. Kesamaan lokasi belanja dan lokasi tempat tinggal tidak selalu mengarahkan pelaku belanja untuk memilih lokasi tersebut. Studi ini menemukan pula bahwa atraksi yang ditawarkan oleh lokasi belanja memengaruhi pemilihan tersebut. Selain itu, pengaturan aktivitas pelaku belanja juga ditemukan memengaruhi pemilihan lokasi belanja, yaitu dengan melakukan pengaturan perjalanan dan aktivitas melalui rantai perjalanan.
\end{abstract}

Kata-kata kunci: belanja kebutuhan sehari-hari, lokasi belanja, karakteristik perjalanan, perilaku perjalanan

\section{PENDAHULUAN}

Kegiatan belanja memainkan peran penting dalam memenuhi kebutuhan individu maupun rumah tangga. Meskipun terdapat pengaruh perkembangan teknologi informasi yang cepat dan luas terhadap kegiatan berbelanja, kegiatan belanja dengan kehadiran secara fisik cenderung masih menjadi pilihan utama masyarakat pada komoditas kebutuhan sehari-hari (Schmid et al., 2016). Hal ini sangat terlihat pada masyarakat di negara berkembang seperti 
Indonesia, yang akses rumah tangga terhadap internetnya masih relatif rendah. Pada tahun 2015, hanya 22,2\% rumah tangga yang memiliki akses ke internet, dan daerah dengan akses terendah adalah kawasan Papua dan Maluku, yaitu 14,1\% (Kemenkominfo, 2016). Selain itu, terdapat berbagai daya tarik kegiatan belanja dengan kehadiran secara fisik.

Secara sistematis, kegiatan berbelanja merupakan rangkaian proses panjang yang dimulai dari pengumpulan informasi hingga pembelian produk (Salomon dan Koppelman, 1988). Rangkaian tersebut termasuk proses pemilihan lokasi, yang merupakan konsekuensi keterbatasan spasial dari pelaku belanja. Untuk hal tersebut, pelaku belanja melakukan pemilihan lokasi belanja dengan mempertimbangkan berbagai faktor, seperti karakteristik demografi, karakteristik lokasi belanja, serta atribut spasial pelaku perjalanan (Recker dan Kostyniuk, 1978).

Studi sebelumnya menemukan bahwa atribut spasial seperti keterhubungan wilayah tempat tinggal dengan lokasi belanja merupakan salah satu pertimbangan pelaku belanja dalam memilih lokasi belanja (Jou dan Mahmassani, 1997). Pelaku belanja cenderung memilih lokasi yang memberikan kemudahan spasial untuk dirinya, baik dalam keterhubungan dengan tempat tinggal maupun lokasi aktivitas lainnya. Selain itu, karakteristik lokasi belanja, seperti daya tarik yang berkembang dalam menyediakan berbagai fasilitas, memengaruhi pemilihan lokasi belanja (Salomon dan Koppelman, 1988). Hal ini dimungkinkan karena pelaku belanja juga secara langsung menghubungkan pemilihan tersebut dengan upaya pemenuhan kebutuhannya yang beragam.

Dengan pentingnya belanja kebutuhan sehari-hari, kegiatan belanja secara fisik berkonsekuensi pada pembentukan perjalanan yang menambah dampak permasalahan perkotaan, misalnya kemacetan. Rendahnya kualitas angkutan umum perkotaan di kotakota di Indonesia ikut menjadikan perjalanan dalam kegiatan sehari-hari bertumpu pada angkutan pribadi (Susilo et al., 2007). Peran belanja dalam pemenuhan kebutuhan individu dan rumah tangga dalam kehidupan sehari-hari sangat penting. Dengan konsekuensi perjalanan yang tercipta dari kegiatan belanja yang membutuhkan kehadiran secara fisik, sangat relevan untuk mempelajari bagaimana perilaku pelaku belanja dalam memilih lokasi belanja. Secara spesifik, informasi mengenai pola dan perilaku berbelanja termasuk pada pemilihan lokasi menjadi penting dalam merumuskan kebijakan perencanaan perkotaan, misalnya untuk memahami bagaimana lokasi belanja berhubungan keterkaitannya dengan lokasi tempat tinggal serta hubungannya dengan karakteristik lokasi belanja. Selain itu, pola pemilihan lokasi ini dapat menjadi masukan untuk merumuskan penyediaan angkutan publik di kawasan belanja yang sesuai dengan pola perjalanan pelaku belanja.

Dengan latar belakang tersebut, studi ini bertujuan untuk memahami bagaimana pelaku belanja memilih lokasi berbelanja kebutuhan sehari-hari. Studi ini mencoba menjawab dua pertanyaan dasar, yaitu (i) bagaimana keterkaitan lokasi spasial lokasi belanja terhadap tempat tinggal dan hubungannya dengan karakteristik belanja, dan (ii) bagaimana pola karatekristik belanja dengan pengaturan aktivitas. 
Kegiatan berbelanja secara fisik telah berkembang untuk menyediakan tidak hanya kegiatan untuk memperoleh barang tertentu tetapi juga peluang dalam memenuhi fungsi kebutuhan interaksi sosial dan hiburan. Dengan banyak dan beragamnya perjalanan, individu berupaya mengefisienkan perjalanannya, yang salah satu upayanya adalah dengan memaksimalkan rantai perjalanan harian mereka dengan memasukkan kegiatan belanja di antara perjalanan mereka. Selain itu, di balik perilaku belanja ada motivasi mendasar seseorang untuk memenuhi kebutuhan atau keinginan mereka.

Pemilihan lokasi belanja merupakan proses penting dalam rangkaian proses belanja. Recker dan Kostyniuk (1978) mengatakan bahwa terdapat tiga aspek penting dalam pertimbangan pemilihan lokasi belanja, yaitu (i) preferensi pelaku belanja terhadap karakteristik lokasi belanja, (ii) preferensi mengenai aksesibilitas menuju lokasi belanja, dan (iii) jumlah pilihan alternatif yang tersedia. Selain itu, proses pertimbangan lokasi belanja merupakan fungsi hubungan antara karakteristik pelaku belanja dan karakteristik lokasi belanja. Pada karakteristik lokasi belanja, juga terdapat pengaruh faktor aksesibilitas dan kenyamanan lokasi tersebut dalam memenuhi kebutuhan pelaku belanja.

Berbagai kebutuhan dan keinginan seseorang menghasilkan pengaturan aktivitas yang beragam dan berkonsekuensi pada pola perjalanan yang telah menarik banyak peneliti. Pengaturan perjalanan tersebut tersusun dalam rentang aktivitas yang berantai. Ketika seseorang mengatur perjalanan hariannya untuk berbagai tujuan dan lokasi, perjalanan sehari-hari biasanya ditunjukkan dalam bentuk rantai perjalanan. Pengaturan rantai perjalanan harian seseorang ini bisa sangat stabil atau sangat acak.

Stabilitas rantai perjalanan umumnya dipengaruhi oleh pola aktivitas atau kebiasaan aktivitas seseorang dan karakteristik sosio-demografi. Perubahan kompleksitas rutinitas orang dan lingkungannya menentukan variabilitas rantai perjalanannya, karena orang tersebut cenderung menyebarkan risikonya dan memenuhi keingintahuannya.

Perjalanan untuk berbelanja dengan kehadiran secara fisik, sebagai manifestasi pemenuhan kebutuhan individu maupun rumah tangga, akan terus dilakukan oleh pelaku belanja dengan daya tarik yang ditawarkannya (Mokhtarian, 2004). Berbagai hal menujukkan bahwa pemilihan lokasi belanja menjadi aspek penting dalam aktivitas belanja di negara maju, sedangkan di negara yang sedang berkembang belum banyak dipelajari. Dengan adanya perbedaan karakteristik antara negara maju dan negara yang sedang berkembang, sangat relevan untuk melakukan studi ini di Indonesia. Pemahaman perilaku dalam memilih lokasi berbelanja yang terkait dengan lokasi tempat tinggal dan dengan rantai perjalanan dapat menjadi dasar perumusan kebijakan manajemen lalu lintas di masa mendatang.

Penelitian ini menggunakan kuesioner yang didistribusikan pada pelaku belanja di rumah tangga di Kota Bandung. Kuesioner tersebut terdiri atas pertanyaan yang mencakup aspek sosio-demografi, seperti pendapatan, status keluarga, dan status rumah, aspek perilaku belanja, termasuk aspek spasial, lokasi belanja atau toko, dan karakteristik perjalanan, serta aspek kondisi lingkungan terbangun, untuk menyelidiki karakteristik lingkungan rumah tangga. Kuesioner dibagikan di 6 wilayah administratif di Kota 
Bandung, yaitu Tegallega, Gede Bage, Ujung Berung, Karees, Cibeunying, dan Bojonagara. Pendistribusian dilakukan dari tanggal 10 hingga 16 Juni 2017 dengan bantuan 27 surveyor. Ukuran sampel 400 ditentukan berdasarkan persamaan Yamane (Israel, 2012) dengan acuan populasi Kota Bandung sebanyak 2.481.469 jiwa (BPS, 2017) dan tingkat signifikansi 5\%. Ukuran sampel ditingkatkan menjadi 520 untuk mengatasi peluang kesalahan selama survei. Setelah selesainya distribusi kuesioner, data dievaluasi berdasarkan kelengkapannya dan diperoleh hasil bahwa semua data dapat digunakan untuk analisis lebih lanjut.

Data menunjukkan bahwa mayoritas responden menggunakan sepeda motor $(41,1 \%)$ untuk mencapai lokasi belanja, sementara 29,4\% menggunakan kendaraan tidak bermotor (NMT), seperti ditunjukkan pada Tabel 1. Sebagian besar responden berusia lebih dari 35 tahun $(62,7 \%)$, dan pendapatan bulanan rumah tangga responden didominasi oleh pendapatan sebesar kurang dari tiga juta rupiah $(33,4 \%)$ dan $29,3 \%$ responden memiliki pendapatan di kisaran 3 hingga 6 juta rupiah. Survei ini juga menangkap 15,3\% responden dengan pendapatan lebih dari dua belas juta rupiah sebagai representasi kelas menengah atas. Sebagai referensi, upah minimum rata-rata bulanan (UMR) untuk Kota Bandung adalah sebesar Rp3.000.000, yang mengacu pada besaran upah tenaga kerja (Pemerintah Provinsi Jawa Barat, 2017).

Tabel 1 Karakteristik Responden $(\mathrm{n}=520)$

\begin{tabular}{|c|c|c|c|c|}
\hline & Variabel & Proporsi & $\begin{array}{c}\text { Chi-Square } \\
\text { (Berdasarkan Rantai } \\
\text { Perjalanan*) }\end{array}$ & $\begin{array}{c}\text { Chi-Square } \\
\text { (Atribut Spasial } \\
\text { Lokasi Belanja**) }\end{array}$ \\
\hline \multirow{6}{*}{ Pendapatan } & $<\mathrm{Rp3} .000 .000,00$ & $33,4 \%$ & \multirow{6}{*}{$19,670(0,000)$} & \multirow{6}{*}{$9,863(0,131)$} \\
\hline & Rp3.000.000,00-Rp6.000.000,00 & $29,3 \%$ & & \\
\hline & Rp6.000.000,00-Rp9.000.000,00 & $13,8 \%$ & & \\
\hline & Rp9.000.000,00-Rp12.000.000,00 & $8,2 \%$ & & \\
\hline & Rp12.000.000,00-Rp15.000.000,00 & $5,8 \%$ & & \\
\hline & $>\mathrm{Rp} 15.000 .000,00$ & $9,5 \%$ & & \\
\hline \multirow{4}{*}{$\begin{array}{c}\text { Moda } \\
\text { Angkutan }\end{array}$} & Sepeda Motor & $41,1 \%$ & \multirow{4}{*}{$20,970(0,000)$} & \multirow{4}{*}{$23,069(0,000)$} \\
\hline & Mobil Pribadi & $18,5 \%$ & & \\
\hline & Angkutan Umum & $11,1 \%$ & & \\
\hline & Pejalan Kaki/Sepeda & $29,4 \%$ & & \\
\hline \multirow{5}{*}{ Usia } & $<18$ Tahun & $1,6 \%$ & \multirow{5}{*}{$8,558(0,073)$} & \multirow{5}{*}{$3,282(0,512)$} \\
\hline & 18-25 Tahun & $15,0 \%$ & & \\
\hline & 26-35 Tahun & $20,7 \%$ & & \\
\hline & 36-50 Tahun & $40,4 \%$ & & \\
\hline & $>50$ Tahun & $22,3 \%$ & & \\
\hline
\end{tabular}

Pada penelitian ini multi-perjalanan didefinisikan sebagai perjalanan yang berisi perjalanan belanja sebagai satu perjalanan di antara beberapa perjalanan lainnya. Sementara perjalanan tunggal terdiri atas perjalanan belanja sebagai satu-satunya tujuan perjalanan. Hasil perbandingan dapat dilihat pada Tabel 1. Data menunjukkan bahwa karakteristik perjalanan berbeda secara signifikan antara perjalanan multi dan perjalanan tunggal, 
termasuk antara jenis atribut spasial lokasi belanja. Hal ini menarik untuk memunculkan hipotesis bahwa lokasi belanja dan lokasi tempat tinggal memiliki hubungan. Hal lain yang juga menarik untuk dicatat adalah bahwa pembagian moda berkendara dan pendapatan ditemukan bervariasi di antara jenis-jenis perjalanan. Hal ini menyiratkan pengaruh pada karakteristik rantai perjalanan dan pengaturan aktivitas belanja.

Selanjutnya dilakukan analisis tabulasi silang lokasi belanja dengan karakteristik perjalanan belanja, yaitu jarak dan waktu perjalanan. Terihat bahwa terdapat variasi distribusi, baik pada jarak maupun waktu perjalanan. Pada wilayah yang berbeda ditemukan bahwa mayoritas pelaku belanja melakukan perjalanan pada jarak (1-5) km, sedangkan pada lokasi dengan wilayah yang sama, mayoritas pada jarak kurang dari $1 \mathrm{~km}$. Pola ini seragam pada waktu perjalanan. Mayoritas pelaku belanja di lokasi yang memiliki wilayah yang sama dengan tempat tinggal memiliki waktu perjalanan kurang dari 30 menit.

\section{ANALISIS}

\section{Klasifikasi Berdasarkan Lokasi Belanja dan Rantai Perjalanan}

Pemilihan lokasi belanja merupakan fungsi spasial sebagai manifestasi dari aspek aksesibilitas ke lokasi belanja. Secara khusus, studi ini menganalisis segmentasi perilaku belanja berdasarkan lokasi kewilayahan menuju lokasi belanja dari lokasi tempat tinggal. Dua buah model diestimasi menggunakan analisis diskriminan. Analisis pertama adalah pengklasifikasian dilakukan berdasarkan kesamaan antara lokasi belanja dengan lokasi tempat tinggal. Ada dua kelompok yang digunakan, yaitu lokasi yang sama dan lokasi yang berbeda antara lokasi belanja dan lokasi tempat tinggal. Analisis dilanjutkan dengan melakukan analisis kedua untuk menyelidiki bagaimana individu mengatur aktivitas belanja mereka di antara rantai perjalanan harian mereka.

Variabel karakteristik sosio-demografi dan belanja dilibatkan dalam model untuk menguji hipotesis mengenai rasionalitas perilaku konsumen yang akan memaksimalkan perjalanannya dengan merencanakan keinginan mereka, mempertimbangkan total biaya, memilih kendaraan, serta melakukan pengaturan perjalanan. Variabel penjelas, yaitu karakteristik tempat tinggal dan moda kendaraan, juga digunakan untuk mempelajari bagaimana individu mengatur aktivitas belanja dan faktor yang memengaruhinya.

Hasil analisis klasifikasi lokasi belanja berdasarkan atribut spasial kewilayahan disajikan pada Tabel 2. Analisis diselesaikan untuk 2 kelompok kewilayahan sebagai variabel dependen dan sosio-demografi, perjalanan, serta karakteristik berbelanja. Hasil uji Box's M menunjukkan bahwa hipotesis awal pada matriks kovariansi populasi yang sama ditolak. Ketika menggunakan uji M Box, M yang tidak signifikan diharapkan bahwa matriks varians-kovarian adalah ekuivalen, namun dengan sampel yang besar, hasil yang signifikan tidak dianggap signifikan (Burns dan Burns, 2008). Interpretasi model bergantung pada fungsi grup centroid yang memisahkan 2 pilihan dengan mengamati nilai paling positif dan nilai paling negatif masing-masing fungsi. Dengan 2 klasifikasi ini, 
hanya ada 1 fungsi yang memisahkan responden yang berbelanja di lokasi belanja dengan kesamaan lokasi tempat tinggal dan tempat belanja $(0,215)$ dan pelaku belanja dengan lokasi belanja yang berbeda dengan lokasi tempat tinggal $(-0,752)$.

Tabel 2 Tabulasi Silang Lokasi Belanja dan Jarak dan Waktu Perjalanan

\begin{tabular}{cccccc}
\hline $\begin{array}{c}\text { Jarak Perjalanan } \\
(\mathrm{Km})\end{array}$ & $\begin{array}{c}\text { Wilayah } \\
\text { Berbeda }\end{array}$ & $\begin{array}{c}\text { Wilayah } \\
\text { Sama }\end{array}$ & $\begin{array}{c}\text { Waktu Perjalanan } \\
\text { (Menit) }\end{array}$ & $\begin{array}{c}\text { Wilayah } \\
\text { Berbeda }\end{array}$ & $\begin{array}{c}\text { Wilayah } \\
\text { Sama }\end{array}$ \\
\hline$<1$ & $24,1 \%$ & $55,3 \%$ & $<30$ & $19,7 \%$ & $40,6 \%$ \\
$1-5$ & $54,3 \%$ & $41,0 \%$ & $31-60$ & $48,7 \%$ & $39,8 \%$ \\
$5-10$ & $13,8 \%$ & $3,3 \%$ & $61-90$ & $22,2 \%$ & $13,0 \%$ \\
$10-15$ & $6,0 \%$ & $0,3 \%$ & $91-120$ & $6,8 \%$ & $4,5 \%$ \\
$>15$ & $1,7 \%$ & $0,3 \%$ & $>120$ & $2,6 \%$ & $2,0 \%$ \\
\hline $\begin{array}{c}\text { Chi-Square } \\
(p \text {-value })\end{array}$ & \multirow{2}{*}{$61,976(0,000)$} & Chi-Square & \multirow{2}{*}{$18,927(0,001)$} \\
\hline
\end{tabular}

Berdasar nilai matriks struktural dapat diketahui bahwa variabel prediktor yang sangat terkait dengan fungsi diskriminan adalah pengeluaran saat belanja, jarak, biaya, dan waktu ke lokasi belanja. Pelaku belanja dengan kewilayahan yang sama berasosiasi dengan pengeluaran belanja yang kurang dari Rp100.000,00, jarak yang kurang dari $1 \mathrm{~km}$, biaya perjalanan yang kurang dari Rp10.000,00, serta waktu perjalanan yang kurang dari 10 menit. Dari sisi pemilihan moda berkendara, pelaku belanja yang berjalan kaki atau bersepeda cenderung memiliki asosiasi lebih tinggi dengan lokasi belanja pada kewilayahan yang sama dengan tempat tinggal. Adapun pelaku belanja dengan kewilayahan berbeda memiliki asosiasi dengan pengeluaran belanja yang lebih dari Rp250.000,00 serta jarak perjalanan lebih dari $10 \mathrm{~km}$. Adapun pemilihan moda pelaku belanja dengan kewilayahan tidak seragam cenderung menggunakan mobil pribadi.

Hasil analisis klasifikasi lokasi belanja berdasarkan tipe rantai perjalanan disajikan pada Tabel 3. Klasifikasi dilakukan untuk 2 jenis rantai perjalanan, yaitu pada perjalanan belanja yang tidak terhubung dengan perjalanan lainnya (Rantai Perjalanan Sederhana) dengan perjalanan belanja yang terhubung dengan perjalanan lainnya (Rantai Perjalanan Kompleks). Hasil uji Box's M pada model ini juga menunjukkan bahwa hipotesis awal matriks kovariansi populasi yang sama ditolak. Hal tersebut bukanlah merupakan isu dalam studi dengan sampel yang besar, seperti studi ini. Dengan 2 klasifikasi, terbentuk 1 fungsi pemisah yang memisahkan responden menjadi pelaku dengan perjalanan belanja sederhana $(0,540)$ serta pelaku perjalanan kompleks $(-0,156)$.

Tabel 3 menunjukkan hasil klasifikasi berdasarkan jenis rantai perjalanan. Interpretasi berdasarkan nilai matriks struktural menunjukkan perbedaan karakteristik antara pelaku belanja yang melakukan rantai perjalanan sederhana dan perjalanan kompleks. Pelaku belanja dengan rantai perjalanan sederhana cenderung memiliki jarak perjalanan kurang dari $1 \mathrm{~km}$ dan pengeluaran kurang dari Rp100.000,00. Dari model tersebut dapat ditemukan pula bahwa pelaku belanja dengan umur lebih dari 57 tahun cenderung melakukan rantai perjalanan sederhana. Untuk tipe kendaraan, pelaku belanja yang berjalan kaki atau bersepeda cenderung melakukan rantai perjalanan sederhana. Di sisi lain, responden dengan jarak perjalanan lebih dari $10 \mathrm{~km}$ cenderung memiliki rantai perjalanan kompleks 
dengan biaya perjalanan lebih dari Rp45.000,00. Model ini juga menunjukkan kecenderungan bahwa pengguna mobil pribadi memiliki rantai perjalanan kompleks.

Tabel 3 Klasifikasi Lokasi Belanja Pelaku Belanja

\begin{tabular}{|c|c|c|c|c|}
\hline \multirow[b]{2}{*}{ Variabel } & \multicolumn{2}{|c|}{ Group Means } & \multirow[b]{2}{*}{$p$-value } & \multirow[b]{2}{*}{$\begin{array}{c}\text { Structure } \\
\text { Matrix }\end{array}$} \\
\hline & $\begin{array}{l}\text { Wilayah } \\
\text { Berbeda }\end{array}$ & $\begin{array}{l}\text { Wilayah } \\
\text { Sama }\end{array}$ & & \\
\hline Pengeluaran Belanja < Rp100.000,00 [D] & 0,2037 & 0,3995 & 0,000 & 0,428 \\
\hline Pengeluaran Belanja > Rp250.000,00 [D] & 0,3056 & 0,164 & 0,001 & $-0,372$ \\
\hline Jarak ke Lokasi Belanja < 1 km [D] & 0,2407 & 0,5608 & 0,000 & 0,685 \\
\hline Jarak ke Lokasi Belanja > 10 km [D] & 0,0741 & 0,0053 & 0,000 & $-0,510$ \\
\hline Waktu ke Lokasi Belanja < 10 mnt [D] & 0,6944 & 0,8942 & 0,000 & 0,593 \\
\hline Waktu ke Lokasi Belanja > 45 mnt [D] & 0,0185 & 0,0079 & 0,337 & $-0,108$ \\
\hline Biaya ke Lokasi Belanja < Rp10.000,00 [D] & 0,7037 & 0,8651 & 0,000 & 0,450 \\
\hline Biaya ke Lokasi Belanja > Rp45.000,00 [D] & 0,0463 & 0,0132 & 0,033 & $-0,241$ \\
\hline$<18$ Tahun $[\mathrm{D}]$ & 0,0093 & 0,0185 & 0,506 & 0,075 \\
\hline 18-25 Tahun [D] & 0,1481 & 0,1429 & 0,890 & $-0,016$ \\
\hline 26-40 Tahun [D] & 0,1759 & 0,2196 & 0,327 & 0,111 \\
\hline > 57 Tahun $[\mathrm{D}]$ & 0,2685 & 0,2116 & 0,212 & $-0,141$ \\
\hline Pengguna Motor [D] & 0,3981 & 0,4021 & 0,941 & 0,008 \\
\hline Pengguna Mobil [D] & 0,287 & 0,1587 & 0,003 & $-0,343$ \\
\hline Pengguna Angkutan Umum [D] & 0,1667 & 0,0979 & 0,047 & $-0,225$ \\
\hline Berjalan Kaki/Bersepeda [D] & 0,1481 & 0,3413 & 0,000 & 0,442 \\
\hline Memiliki Kendaraan Pribadi [D] & 0,9907 & 0,9709 & 0,242 & $-0,132$ \\
\hline Melakukan Rantai Perjalanan Complex [D] & 0,7130 & 0,7910 & 0,088 & 0,193 \\
\hline Tipe Rumah > 145 m2 [D] & 1,1204 & 1,1534 & 0,392 & 0,097 \\
\hline Box's M [F;df1;df2;p-value $]$ & \multicolumn{2}{|c|}{$\begin{array}{c}787,780[4,319 ; 171 ; \\
125707,27 ; 0,000]\end{array}$} & $\begin{array}{l}\text { Wilayah } \\
\text { Belanja }\end{array}$ & F1 \\
\hline Eigen Values [Canonical Correlation] & \multicolumn{2}{|c|}{$0,162[0,374]$} & Sama & 0,215 \\
\hline Wilks' Lambda F1 [p-value] & \multicolumn{2}{|c|}{$0,860[0.000]$} & Tidak Sama & $-0,752$ \\
\hline
\end{tabular}

[D] = Dummy 1 ya; 0 lainnya

Tabel 4 Klasifikasi Rantai Perjalanan Pelaku Belanja

\begin{tabular}{|c|c|c|c|c|}
\hline \multirow{2}{*}{ Variabel } & \multicolumn{2}{|c|}{ Group Means } & \multirow{2}{*}{ p-value } & \multirow{2}{*}{$\begin{array}{c}\text { Structure } \\
\text { Matrix }\end{array}$} \\
\hline & Complex & Direct & & \\
\hline Pengeluaran Belanja $<$ Rp100.000,00 [D] & 0,2613 & 0,3828 & 0,018 & $-0,366$ \\
\hline Jarak ke Lokasi Belanja $<1$ km [D] & 0,3063 & 0,5443 & 0,000 & $-0,696$ \\
\hline Jarak ke Lokasi Belanja > 10 km [D] & 0,0541 & 0,0104 & 0,004 & 0,448 \\
\hline Waktu ke Lokasi Belanja < 10 mnt [D] & 0,7838 & 0,8698 & 0,025 & $-0,348$ \\
\hline Biaya ke Lokasi Belanja < Rp10.000,00 [D] & 0,7838 & 0,8438 & 0,139 & $-0,23$ \\
\hline Biaya ke Lokasi Belanja > Rp45.000,00 [D] & 0,0450 & 0,013 & 0,035 & 0,328 \\
\hline 18-25 Tahun $[\mathrm{D}]$ & 0,1892 & 0,1354 & 0,160 & 0,218 \\
\hline > 57 Tahun [D] & 0,1532 & 0,2448 & 0,042 & $-0,316$ \\
\hline Pengguna Mobil [D] & 0,2703 & 0,1589 & 0,008 & 0,415 \\
\hline Pengguna Angkutan Umum [D] & 0,1532 & 0,099 & 0,110 & 0,248 \\
\hline Berjalan Kaki/Bersepeda [D] & 0,1441 & 0,3438 & 0,000 & $-0,636$ \\
\hline Box's M [F;df1;df2;p-value $]$ & \multicolumn{2}{|c|}{$\begin{array}{l}319,859[4,666 ; 66 ; \\
137651,997 ; 0,000]\end{array}$} & $\begin{array}{c}\text { Rantai } \\
\text { Perjalanan }\end{array}$ & $\mathrm{F} 1$ \\
\hline Eigen Values [Canonical Correlation] & \multicolumn{2}{|c|}{$0,085[0,279]$} & Complex & 0.540 \\
\hline Wilks' Lambda F1 [p-value] & \multicolumn{2}{|c|}{$0,922[0.000]$} & Direct & -0.156 \\
\hline
\end{tabular}

[D] = Dummy 1 ya; 0 lainnya 


\section{DISKUSI}

Kegiatan berbelanja dengan kehadiran secara fisik masih memiliki daya tarik yang terus bertahan dengan perkembangan fungsi dari lokasi belanja maupun alasan perilaku berbelanja dari pelaku belanja yang berkonsekuensi pada kebutuhan perjalanan. Keputusan untuk terlibat dalam aktivitas belanja secara fisik menuntut pelaku belanja untuk memaksimalkan utilitas perjalanannya dengan mempertimbangkan semua kendala. Hal ini dimanifestasikan dengan pemilihan lokasi belanja serta melakukan penyesuaian perjalanan dengan kegiatan sehari-hari lainnya. Studi ini mencoba untuk memahami perilaku pelaku belanja dalam memilih lokasi belanja kebutuhan sehari-hari dan menyelidiki pengaturan aktivitas dalam hubungannya terhadap kegiatan belanja. Pemilihan lokasi belanja sangat berkait dengan ruang spasial dan waktu kegiatan belanja tersebut. Konsekuensi tersebut terlihat pada temuan studi ini. Dengan menggunakan asosiasi kesamaan lokasi belanja dan lokasi tempat tinggal, tampak kesesuaian dengan alasan pelaku belanja yang memilih jarak, waktu, dan perjalanan rendah.

Adapun temuan menarik nampak pada pengeluaran belanja yang ditemukan rendah pada lokasi belanja dengan kesamaan wilayah, sedangkan pengeluaran yang lebih besar terjadi pada lokasi belanja yang berbeda dengan tempat tinggal. Temuan ini sangat berhubungan dengan 2 aspek. Aspek pertama adalah kebutuhan dan karakteristik lokasi belanja. Barang kebutuhan harian memiliki kecenderungan tersedia pada toko-toko kecilmenengah. Toko-toko tersebut tersedia pada jarak yang terjangkau dari tempat tinggal pelaku perjalanan. Bila dikaitkan dengan pola perkotaan saat ini, lokasi tersebut berada pada sisi luar perkotaan. Sebaliknya lokasi belanja dengan variasi pilihan besar terdapat pada pusat perkotaan yang memiliki jarak cukup jauh dari lokasi tempat tinggal. Variasi barang pada toko tersebut berdampak pada pola pengeluaran yang lebih besar. Diduga kegiatan belanja pada lokasi tersebut dilakukan untuk memenuhi kebutuhan yang lebih panjang dari kebutuhan harian yang tidak dapat dipenuhi pada lokasi belanja di sekitar lokasi tempat tinggal. Aspek kedua adalah pengaruh pengaturan perjalanan. Kecenderungan belanja dengan kehadiran secara fisik memiliki hubungan yang kuat dengan pengaturan aktivitas, khususnya untuk pekerja perorangan yang memiliki lebih banyak aktivitas di luar rumah. Konsep dasar rantai kegiatan menyatakan bahwa pelaku perjalanan mengatur aktivitasnya untuk memaksimalkan penggunaan waktu yang dimanifestasikan dengan rantai perjalanan.

Selanjutnya, temuan mengenai rantai perjalanan untuk perjalanan belanja dalam model kedua juga mendukung studi sebelumnya mengenai interaksi pilihan moda dan rantai perjalanan. Hal ini dikarenakan kegiatan belanja dengan kehadiran secara fisik membangkitkan kebutuhan perjalanan, sehingga pelaku belanja akan memaksimalkan penggunaan waktunya di rentang waktu dan spasial yang dimiliki. Hal tersebut dilakukan pelaku belanja dengan merangkai aktivitas belanja dengan aktivitas lain, misalnya pelaku 
perjalanan dapat membuat perhentian pada perjalanan pulang-kerja untuk berbelanja dengan mencari lokasi belanja yang sejalan dengan perjalanan mereka.

Studi ini menemukan bahwa perjalanan rumah-belanja-rumah memiliki karakteristik pelaku belanja yang memiliki lokasi belanja dekat dan berpengeluaran rendah. Adapun rantai aktivitas dalam kegiatan multitrip kemungkinan besar terjadi dalam jarak perjalanan yang lebih jauh karena pertimbangan jarak lokasi belanja ke lokasi aktivitas selanjutnya. Perlu dicatat lebih lanjut bahwa perjalanan tunggal juga terkait dengan pembeli yang lebih senior, yang berumur lebih dari 57 tahun.

\section{KESIMPULAN}

Hasil studi ini mengkonfirmasi dugaan bahwa pemilihan lokasi belanja untuk kegiatan belanja secara fisik sangat berhubungan dengan pengaturan aktivitas dan pola aktraksi lokasi belanja. Temuan tersebut mengindikasikan bahwa kebijakan manajemen perkotaan merupakan poin penting, khususnya penyediaan lokasi belanja yang mendekati lokasi tempat tinggal. Pola atraksi lokasi belanja memerlukan penyesuaian dengan lokasi aktivitas. Selain itu, pola pengaturan aktivitas yang berhubungan dengan kegiatan belanja menandakan perlunya manajemen angkutan umum yang melayani aktivitas belanja dengan layanan dan jaringan yang terhubung dengan aktivitas lainnya.

Meskipun telah banyak informasi yang diperoleh dari studi ini, namun terdapat keterbatasan dalam analisis. Salah satunya adalah rangkaian aktivitas individu dalam rentang 1 hari yang tidak terakomodasi pada studi ini. Pemahaman pola rangkaian aktivitas dalam ruang 1 hari akan memberi gambaran informasi kegiatan belanja secara penuh serta hubungannya dengan kegiatan lainnya. Selain itu, pola perjalanan antarhari yang berbeda memunculkan kepentingan untuk melihat pola kestabilan kegiatan belanja pada rentang waktu 1 minggu atau lebih. Karakteristik hari ke hari yang dapat sangat berbeda atau mungkin sangat seragam akan memberi informasi yang lebih sempurna dalam membuat kebijakan manajemen perjalanan.

\section{UCAPAN TERIMA KASIH}

Studi ini didanai oleh Direktorat Penelitian dan Pengabdian Masyarakat, Direktorat Jenderal Penguatan Riset dan Pengembangan, Kementerian Riset, Teknologi, dan Pendidikan Tinggi, Republik Indonesia, melalui Kontrak Riset Nomor 1598/K4/KM/2017. Penulis mengucapkan terima kasih kepada semua pihak yang telah berpartisipasi dalam pengumpulan data. 


\section{DAFTAR PUSTAKA}

Burns, R. dan Burns, R. 2008. Business Research Methods dan Statistics Using SPSS. Newbury Park, CA: Sage Publications, Ltd.

Israel, G.D. 2012. Determining Sample Size, PEOD6. Agricultural Education and Communication Department, Florida Cooperative Extension Service, Institute of Food dan Agricultural Sciences, University of Florida, Gainesville, FL.

Jou, R.C. dan Mahmassani, H.S. 1997. Comparative Analysis of Day-to-Day Trip-Chaining Behaviour of Urban Commuters in Two Cities. Transportation Research Record 1607, hlm. 163-170.

Kementerian Komunikasi dan Informatika Republik Indonesia. 2016. Lampiran Peraturan Menteri Komunikasi dan Informatika Nomor 21 Tahun 2016. Rencana Strategis Kementerian Komunikasi dan Informatika 2015-2019. Jakarta.

Mokhtarian, P.L. 2004. A Conceptual Analysis of the Transportation Impacts of B2C ECommerce. Transportation, 31 (3): 257-284.

Pemerintah Provinsi Jawa Barat. 2017. Keputusan Gubernur Provinsi Jawa Barat Nomor 561/Kep.1065-yangbangsos/2017 tentang Upah Minimum Kabupaten/Kota di Daerah Provinsi Jawa Barat Tahun 2018. Bandung.

Recker, W.W. dan Kostyniuk, L.P. 1978. Factors Influencing Destination Choice for the Urban Groceries Trip. Transportation, 7: 19-33.

Salomon, I. dan Koppelman F. 1988. A framework for Studying Teleshopping versus Store Shopping. Transportation Research Part A, 22 (4): 247-255.

Schmid, B., Schmutz, S., dan Axhausen, K.W. 2016. Exploring the Choice between inStore and Online Shopping. In $23^{\text {rd }}$ International Conference on Recent Advances in Retailing and Service Strategies (EIRASS 2016). IVT, ETH Zurich.

Strathman, J.G. dan Dueker, K.J. 1995. Understanding Trip Chaining. 1990 NPTS Special Reports on Trip and Vehicle Attributes. Publication FHWA-PL-95-033. FHWA, US Department of Transportation.

Susilo, Y.O., Santosa, W., Joewono, T. B., dan Parikesit, D. 2007. A Reflection of Motorization and Public Transport in Jakarta Metropolitan Area. IATSS Research, 31 (1): 59-68. 